\title{
Targeting the $\mathbf{9 0} \mathrm{kDa}$ Heat Shock Protein Improves Photodynamic Therapy
}

\author{
Angela Ferrario ${ }^{a}$ and Charles J. Gomera,b, ${ }^{*}$ \\ aThe Saban Research Institute, Childrens Hospital Los Angeles, Los Angeles, CA 90027, USA \\ ${ }^{b}$ Departments of Pediatrics and Radiation Oncology, Keck School of Medicine, University of \\ Southern California, Los Angeles, CA 90027.
}

\begin{abstract}
The geldanamycin derivative, 17-allylamino-17-demethoxygeldanamycin (17-AAG), binds to the amino-terminal ATP binding pocket of the $90 \mathrm{kDa}$ heat shock protein (Hsp-90) and inhibits this chaperone from stabilizing client proteins involved with the malignant phenotype. We examined the effects of a combined modality protocol involving photodynamic therapy (PDT) and 17-AAG in mouse mammary carcinoma cells and tumors. PDT increased the expression of the anti-apoptotic and pro-angiogenic proteins survivin, Akt, HIF-1 $\alpha$, MMP-2 and VEGF in tumor tissue and this expression decreased significantly when 17-AAG was included in the treatment regimen. Tumor bearing mice treated with PDT and 17-AAG had improved long-term tumoricidal responses when compared with individual treatment protocols. We conclude that Hsp-90 plays an active role in modulating tumor responsiveness following PDT and targeting Hsp-90 with 17-AAG enhances the therapeutic effectiveness of PDT.
\end{abstract}

\section{Keywords}

photodynamic therapy; PDT; apoptosis; Hsp-90; 17-AAG; geldanamycin

\section{Introduction}

Photodynamic therapy (PDT) is used for treating malignant and non-oncologic disorders [1]. The treatment involves either the systemic injection of a photosensitizer or topical application of a prodrug followed by exposure of the target lesion to visible light [1,2]. The FDA approved photosensitizer, Photofrin ( $\mathrm{PH})$, as well as a variety of second generation photosensitizes are in PDT clinical trials [1-3]. Photochemical generation of cytotoxic reactive oxygen species within the treatment field leads to direct and indirect responses. Direct cell killing of the tumor occurs via necrosis, apoptosis and autophagy [4,5]. Indirect responses within the tumor microenvironment include vascular injury, hypoxia and inflammatory reactions $[6,7]$.

Molecular actions following PDT involve increased expression of regulators of angiogenic and

() 2009 Elsevier Ireland Ltd. All rights reserved.

*Corresponding author. Address: Childrens Hospital Los Angeles, Mail Stop 67, 4650 Sunset Boulevard, Los Angeles, CA 90027, USA. Tel: 323-361-2335, Fax: 323-361-4806, cgomer@chla.usc.edu.

Publisher's Disclaimer: This is a PDF file of an unedited manuscript that has been accepted for publication. As a service to our customers we are providing this early version of the manuscript. The manuscript will undergo copyediting, typesetting, and review of the resulting proof before it is published in its final citable form. Please note that during the production process errors may be discovered which could affect the content, and all legal disclaimers that apply to the journal pertain.

Conflict of Interest

There were no conflicts of interest associated with this work for either author. 
apoptotic pathways including growth factors [6,8,9] matrix metalloproteinases [10] cytokines $[7,11]$, prostanoids [11,12], signaling molecules $[2,4,13]$ and members of the inhibitor of apoptosis (IAP) family [14]. Methods to improve PDT responsiveness are now examining combined modality approaches targeting these molecules and pathways.

The heat shock protein (Hsp) family functions as molecular chaperones and guide the folding, intracellular localization and proteolytic turnover of key regulators of cell growth,

differentiation and survival. The $90 \mathrm{kDa} \mathrm{Hsp}(\mathrm{Hsp}-90)$ comprises 1-2\% of the total intracellular protein in normal eukaryotic cells, is constitutively over expressed in tumor cells, and is being evaluated as a target for cancer therapy $[15,16]$. Hsp-90 controls the balance between folding/ maturation and proteasomal degradation of client proteins and is involved in promoting the growth and survival of malignant cells and tumors [15-18]. Geldanamycin and the clinically relevant derivative, 17-allylamino-17-demethoxygeldanamycin (17-AAG), bind to the aminoterminal ATP binding pocket of Hsp-90 and block the ability of this chaperone to properly fold or stabilize client proteins [15,19]. 17-AAG displays higher affinity for Hsp-90 derived from tumor cells compared to Hsp-90 from normal cells [20]. Hsp-90 inhibitors synergize with chemotherapeutic agents and radiation and cause the destabilization and degradation of HIF-1 $\alpha[20,21]$. We recently reported that $17-A A G$ attenuates PDT-induced expression of survivin and Akt and enhances apoptosis in a human breast cancer cell line [14]. The goal of the current study was to expand upon these findings by determining the effectiveness of 17-

AAG in improving the in vivo tumoricidal action of PDT using a mouse mammary carcinoma model. We demonstrate for the first time that 17-AAG increases the efficacy of the PDT tumor treatment and suggest that a combined modality approach targeting multiple pathways maintained by Hsp-90 may be a beneficial adjuvant for PDT.

\section{Materials and Methods}

\subsection{Drugs}

The photosensitizer Photofrin porfimer sodium (PH) (a gift from Axcan Pharma, Mont-SaintHilaire, QC, Canada) was dissolved in $5 \%$ dextrose in water to make a $2.5 \mathrm{mg} / \mathrm{ml}$ stock solution and frozen at $-20 \mathrm{C}$ until used. The stock solution was diluted to $25 \mu \mathrm{g} / \mathrm{ml}$ in culture medium prior to in vitro experiments or to a concentration of $0.5 \mathrm{mg} / \mathrm{ml}$ in saline prior to in vivo studies. 17-AAG (provided by the Cancer Treatment and Evaluation Program, National Cancer Institute, Bethesda, MD) was dissolved in dimethylsulfoxide (DMSO) to make a stock concentration of $1 \mathrm{mM}$ for in vitro experiments and $100 \mathrm{mM}$ for in-vivo studies. The 17-AAG stock solutions were kept at $-20 \mathrm{C}$ and diluted to $1 \mu \mathrm{M}$ with medium immediately before in vitro experiments and to a concentration of $10 \mathrm{mM}$ in saline before in-vivo administration.

\subsection{Cell Culture and Tumor Models}

Mouse mammary carcinoma (BA) cells were grown as monolayer cultures in RPMI 1640 and supplemented with $10 \%$ FCS plus antibiotics. BA tumors were generated by subcutaneous trochar injection of 1-mm ${ }^{3}$ pieces of tumor to the right hind flank of 8- to 12-week-old female $\mathrm{C} 3 \mathrm{H} / \mathrm{HeJ}$ mice [10]. Treatments were started when tumors reached 6-7 $\mathrm{mm}$ in diameter. All in vivo experiments were approved by our institutional animal care and use committee.

\subsection{In vitro and In vivo Treatment Protocols}

BA cells were seeded onto plastic Petri dishes and incubated for 24 hours in complete growth medium to allow for attachment [10]. Prior to light exposure, cells were incubated in the dark with PH at a dose of $25 \mu \mathrm{g} / \mathrm{ml}$ for 16 hours at $37 \mathrm{C}$. Cells were then incubated for an additional 30 minutes in fresh growth medium containing 5\% FCS and rinsed in medium without serum prior to exposure to varying doses of broad spectrum $(570-650 \mathrm{~nm})$ red light generated by a parallel series of red Mylar-filtered $30 \mathrm{~W}$ fluorescent bulbs delivered at a dose rate of 0.35 
$\mathrm{mW} / \mathrm{cm}^{2}$. For combination experiments, PDT treated cells were incubated for an additional 24 hours with growth medium in the presence or absence of 17-AAG. In-vivo PDT treatment of BA tumors included an i.v. injection of $\mathrm{PH}(5 \mathrm{mg} / \mathrm{kg})$ followed 24 hours later with non-thermal laser irradiation of the tumor using a solid-state diode laser (Diomed, Andover, MA) emitting red light at $630 \mathrm{~nm}$ [12]. Light was delivered via quartz fiber microlens and outputs were measured with a power meter. A light dose rate of $75 \mathrm{~mW} / \mathrm{cm}^{2}$ and a total light dose of $200 \mathrm{~J} /$ $\mathrm{cm}^{2}$ were used for all in-vivo PDT treatments. 17-AAG was administered via ip injection at a dose of $75 \mathrm{mg} / \mathrm{kg}$ thrice weekly $(\mathrm{M}, \mathrm{W}, \mathrm{F})$ for up to two weeks. Mice were monitored three times per week for detection of tumor recurrence and regrowth measurements. A treatment cure was defined as being tumor free for 90 days after PDT.

\subsection{Western Immunoblot Analysis}

Protein expression profiles were obtained by Western immunoblot analysis as previously described [11,12]. Briefly, cells were collected at specified times after treatment and sonicated in 1X lysis buffer containing phenylmethanesulfonyl fluoride from Cell Signaling Technology (Danvers, MA). Tumor samples were collected either 2 or $24 \mathrm{hr}$ following treatment, homogenized with a polytron in $1 \mathrm{X}$ reporter lysis buffer from Promega (Madison, WI) and evaluated for protein expression. Protein samples were size-separated on discontinuous polyacrylamide gels (10-16\%) and transferred overnight to nitrocellulose membranes. Filters were blocked for 2 hours with 5\% nonfat milk and then incubated overnight with either rabbit polyclonal antibody to phospho-survivin (Thr34) from Novus Biologicals (Littleton, CO), rabbit polyclonal antibody to survivin from Chemicon International (Temecula, CA), rabbit polyclonal antibody to Akt1/2 or Raf-1 from Santa Cruz Biotechnology (Santa Cruz, CA), mouse monoclonal antibody to HIF- $1 \alpha$ from Transduction Laboratory (Lexington, KY), rabbit polyclonal antibody to Ser473 phospho-Akt from Cell Signaling Technology (Danvers, MA) rabbit polyclonal Hsp-90 antibody and mouse monoclonal antibody to Hsp70/Hsc70 from Stressgen Bioreagents (Victoria, BC, Canada). Filters were then incubated with either an antimouse or an anti-rabbit peroxidase conjugate from Sigma (St. Louis, MO), and the resulting complexes were visualized by enhanced chemiluminescence autoradiography from Amersham Life Science (Chicago, IL). Protein loading was evaluated by incubating the same filters with a mouse monoclonal anti-actin antibody from MP Biochemicals (Aurora, $\mathrm{OH}$ ).

Autoradiographs were quantified by scanning densitometry.

\subsection{ELISA Assay}

A Quantikine M mouse ELISA kit from R\&D Systems (Minneapolis, MN) was used according to the manufacturer's instructions to quantify VEGF levels in control and treated tumor lysates [9]. Results were normalized for total protein concentrations.

\subsection{SDS-PAGE Zymography}

Aliquots from tumor lysates were denatured, run on $10 \%$ gelatin gels from Invitrogen Life Technologies (Carlsbad, CA) and renatured as previously described [10]. Gels were stained with $0.5 \%$ Coomassie Blue, destained in a solution containing $10 \%$ methanol and $7.5 \%$ acetic acid, and dried [10]. Proteins having gelatinolytic activity were visualized as white bands on a blue gel.

\subsection{Statistics}

The log-rank test was used to compare differences between treatment groups for analysis of tumor cure rates. Differences with $\mathrm{P}<0.05$ were considered significant. 


\section{Results}

\subsection{7-AAG inhibits Hsp-90 function in BA mammary carcinoma cells and tumors}

The biological activity of 17-AAG was first evaluated by examining the expression profiles of the biomarkers Raf-1 and Hsp-70 in BA cells and tumors exposed to the geldanamycin derivative. Raf-1 is a proto-oncogene with serine/threonine kinase activity. Raf-1 is also an Hsp-90 client protein and the expression of this molecule is blocked via a direct interaction of 17-AAG on Hsp-90 function. Conversely, expression of the Hsp-70 molecular chaperone increases following 17-AAG exposure. Levels of these two biomarkers are used to monitor the efficacy of Hsp-90 inhibitors [22]. Figure 1A and B show representative Western immunoblot results following exposure of BA cells and tumors to 17-AAG respectively. Raf-1 expression was blocked following exposure to 17-AAG while the level of Hsp-70 was increased. These results confirm the in vitro and in vivo efficiency of the 17-AAG doses used in our PDT studies to target Hsp-90 chaperone activity.

\subsection{7-AAG blocks cellular expression of PDT-induced pro-survival molecules}

Photofrin mediated PDT, at doses producing between 20-40 percent clonogenic cytotoxicity [12], induces cellular expression and phosphorylation-mediated activation of the Hsp-90 client proteins survivin and Akt. Figure 2A provides representative Western immunoblots showing expression of Akt, Ser473 phospho-Akt, survivin and Thr34 phospho-survivin levels in cells exposed to PDT, 17-AAG or PDT plus 17-AAG. The PDT treatment resulted in the increased expression of survivin, phospho-survivin and phospho-Akt. Combining PDT with 17-AAG decreased the expression of these proteins but did not alter the expression profiles of Hsp-90 or actin. Densitometric averages for three separate experiments are shown in Fig 2 (B-F) for Akt, phospho-Akt, survivin, phospho-survivin and Hsp-90 respectively and confirmed the reproducibility of the inhibitory effects of 17-AAG on the expression of these Hsp-90 client proteins.

\subsection{7-AAG blocks the expression of angiogenic and pro-survival molecules in PDT treated tumors}

We next examined the in vivo expression profiles of the Hsp-90 client proteins Akt, HIF-1 $\alpha$ and survivin in BA tumors following exposure to PDT and/or 17-AAG. Tumors received a $200 \mathrm{~J} / \mathrm{cm}^{2}$ PDT dose. One group of mice received a $75 \mathrm{mg} / \mathrm{kg}$ ip dose of $17-A A G$ delivered immediately following light exposure. Mice were sacrificed two hours following PDT and the tumors were removed for protein analysis. Figures $3 \mathrm{~A}$ and B show Western immunoblots and corresponding protein densitometric measurements for tissue lysates from tumors exposed to PDT, 17-AAG or PDT plus 17-AAG. Administration of 17-AAG resulted in decreased expression of HIF-1 $\alpha$, Akt and survivin within treated tumors. The reduced expression of Akt and survivin was accompanied by a concomitant decrease of their active phosphorylated forms. As expected, 17-AAG did not alter the expression of Hsp-90 or actin. Expression of survivin/ phospho-survivin was also observed in tumor tissues assayed 24 hours post PDT and the combination protocol of PDT and 17-AAG also attenuated expression of this anti-apoptotic protein at this time period (data not shown).

\subsection{7-AAG attenuates PDT expression of VEGF and MMPs in tumor tissue}

BA tumors were treated with either PDT, 17-AAG or PDT \pm 17-AAG as described above and tissue samples were then collected 24 hours later and evaluated for MMP expression/activity via SDS-PAGE gelatinase zymography and for VEGF levels using a commercial ELISA kit. Figures $4 \mathrm{~A}$ and $\mathrm{B}$ show zymographic results and corresponding densitometric reading of MMP expression. PDT induced increased expression and activation of MMP-2 and MMP-9. The addition of 17-AAG to the treatment protocol inhibited the PDT-induced expression and 
proteolytic activation of these MMPs. Figure $4 \mathrm{C}$ shows that PDT induced expression of VEGF within treated tumor tissue was reduced to background values when 17-AAG was combined with PDT. These results demonstrate that 17-AAG effectively attenuates invasion and angiogenic molecules induced within PDT treated tissue.

\subsection{7-AAG enhances PDT treatment of BA mammary tumors}

The therapeutic effectiveness of combining 17-AAG with a standard PDT protocol was evaluated with the same BA mammary tumor model described above to examine Hsp-90 client protein expression profiles. Tumors measuring 6-7 $\mathrm{mm}$ in diameter were treated with PDT using a light dose of $200 \mathrm{~J} / \mathrm{cm}^{2}$. Immediately after PDT, one group of mice was started on a two-week regimen of 17-AAG $(75 \mathrm{mg} / \mathrm{kg}$ ) administered thrice weekly (M,W,F). Tumor response was monitored for a 90-day period. Figure 5 shows the percentage of tumor-free mice as a function of days after treatment for mice receiving 17-AAG, PDT or PDT combined with 17-AAG. The 17-AAG alone protocol did not result in any long-term tumor cures but did result in a 2-3 day delay in tumor regrowth (data not shown). PDT alone resulted in a $25 \%$ cure rate while the combination protocol of PDT and 17-AAG resulted in 50\% long-term cures. The differences between PDT and PDT plus 17-AAG were found to be statistically significant $(\mathrm{p}<0.5)$.

\section{Discussion}

PDT is a first line therapy for cutaneous and bronchial malignancies and is an effective treatment option for multiple tumor types following recurrence after chemotherapy or radiation therapy $[23,24]$. However, similar to other treatment modalities, PDT mediated oxidative stress also induces the expression of prosurvival and angiogenic signaling molecules within the tumor microenvironment which can negatively impact treatment effectiveness [6,7,25-28].

Preclinical studies confirm that targeting individual signaling, anti-apoptotic or angiogenic molecules during PDT can improve therapeutic efficacy but may not maximize treatment responsiveness due to the overlapping pathways of many proteins that promote tumor survival and growth $[8,9,10,26]$. The molecular chaperone Hsp-90 has emerged as a target for cancer therapy because of its role in maintaining the conformation, stability and activity of multiple oncogenic client proteins including several induced by PDT [21]. Inhibiting Hsp-90 activity induces pleiotrophic effects including interference with sustained angiogenesis, avoidance of apoptosis, growth factor independence, unlimited replication, and blockage of tissue invasion and metastasis $[21,22]$. The goal of our study therefore was to determine if a combined modality approach involving PDT together with targeted inhibition of Hsp-90 could enhance tumoricidal activity in a murine mammary carcinoma.

We examined the tumoricidal effects of 17-AAG with PDT due to the inhibitor's clinical relevance and availability as well as to follow up on our previous observation that 17-AAG increases PDT-mediated apoptosis in a human breast cancer cell line [14,29-31]. 17-AAG interacts directly with the Hsp-90 amino-terminus ATP binding site and this leads to client protein destabilization and ubiquitin labeling followed by proteosome mediated degradation $[20,21,29]$. Phase I and II clinical trials suggest that $17-\mathrm{AAG}$ is well tolerated and can inhibit Hsp-90 client proteins in a variety of maligancies including those relevant to PDT such as carcinomas of the breast and prostrate [30,31]. However, exposure to 17-AAG increases expression of Hsp-70 and up-regulation of this stress protein can induce an anti-apoptotic phenotype within cancer cells and may be detrimental to the anticancer activity of geldanamycin derivatives [18]. A definitive role of Hsp-70 on PDT sensitivity has not been obtain [32-34] but increases in 17-AAG mediated Hsp-70 expression may negatively modify combined modality protocols. In this regard, we administered 17-AAG after PDT in order to take advantage of the rapid decrease in tumor mass following laser irradiation as well as to 
minimize any effects of 17-AAG mediated Hsp-70 expression on PDT responsiveness. Currently there are approximately twenty Hsp-90 inhibitors in various stages of development and this includes studies to identify effective Hsp-90 inhibitors that do not increase Hsp-70 expression $[20,21,29]$. Shepherdin, a peptidomimetic inhibitor of the survivin-Hsp-90 complex acts upon a different portion of the ATP binding site than 17-AAG, eliminates expression of Hsp-90 client proteins, does not alter HSP-70 expression, and is being tested as an alternative to geldanamycin derivatives [35].

Our results clearly illustrate the potential for targeting multiple signaling pathways and oncogenic molecules via Hsp-90 inhibition during PDT. Western immunoblot analysis confirmed that 17-AAG administered after in vivo PDT effectively blocks client protein expression. Nevertheless, vascular damage and inflammation associated with PDT may alter the pharmacokinetics of 17-AAG localization within tumor tissue. Our 17-AAG administration procedure of thrice weekly injections of $75 \mathrm{mg} / \mathrm{kg}$ for two weeks is a less aggressive protocol than other in vivo studies and this may have played a role in why we observed only a doubling of the long-term tumoricidal response (from 25 to 50 percent long-term cures) when PDT was combined with 17-AAG [36]. It will be important to optimize this treatment regimen in order to more thoroughly understand the therapeutic options of this combination.

In summary, our data supports the premise that a functional Hsp-90 chaperone can negatively impact PDT-mediated tumoricidal responses by stabilizing client proteins with prosurvival and angiogenic properties. These observations provide a strong rationale for targeting Hsp-90 as an adjunctive therapy to PDT.

\section{Acknowledgments}

We thank Axcan Pharma, Inc., Mont-Saint-Hilaire, QC, Canada for the gift of Photofrin. This research was support in part by NIH grants RO1 CA31230 and RO1 CA119907, the Neil Bogart Memorial Fund of the Martell Foundation for Leukemia, Cancer, and Aids Research, and the Las Madrinas Endowment for Experimental Therapeutics.

\section{References}

1. Dougherty TJ, Gomer CJ, Henderson BW, Jori G, Kessel D, Korbelik M, Moan J, Peng Q. Photodynamic Therapy. J. Natl. Cancer Inst 1998;90:889-905. [PubMed: 9637138]

2. Oleinick NL, Evans HH. The photobiology of photodynamic therapy: cellular targets and mechanisms. Radiat. Res 1998;150:s146-s156. [PubMed: 9806617]

3. Dolmans DE, Fukamura D, Jain RK. Photodynamic therapy of cancer. Nat. Rev. Cancer 2003;3:380387. [PubMed: 12724736]

4. Moor AC. Signaling pathways in cell death and survival after photodynamic therapy. J. Photochem. Photobiol. B-Biology 2000;57:1-13.

5. Kessel D, Reiners JJ. Apoptosis and autophagy after mitochondrial or endoplasmic reticulum photodamage. Photochem. Photobiol 2007;83:1024-1028. [PubMed: 17880495]

6. Gomer CJ, Ferrario A, Luna M, Rucker N, Wong S. Photodynamic therapy: combined modality approaches targeting the tumor microenvironment. Lasers Surg. Med 2006;38:516-521. [PubMed: 16607618]

7. Gollnick SO, Evans SS, Baumann H, Owczarczak B, Maier P, Vaughan L, Wang WC, Unger E, Henderson BW. Role of cytokines in photodynamic therapy-induced local and systemic inflammation. Br. J. Cancer 2002;88:1772-1779. [PubMed: 12771994]

8. Ferrario A, Tiehl KFvon, Rucker N, Schwarz MA, Gill PS, Gomer CJ. Anti-angiogenic treatment enhances photodynamic therapy responsiveness in a mouse mammary carcinoma. Cancer Res 2000;60:4066-4069. [PubMed: 10945611]

9. Ferrario A, Gomer CJ. Avastin enhances photodynamic therapy treatment of Kaposi's sarcoma in a mouse tumor model. J. Environ. Pathol. Oncol 2006;25:251-259. 
10. Ferrario A, Chantrain CF, Tiehl Kvon, Buckley S, Rucker N, Shalinsky DR, Shimada H, DeClerck YA, Gomer CJ. The matrix metalloproteinase inhibitor Prinomastat enhances photodynamic therapy responsiveness in a mouse tumor model. Cancer Res 2004;64:2328-2332. [PubMed: 15059880]

11. Ferrario A, Tiehl KFvon, Wong S, Luna M, Gomer CJ. Cyclooxygenase-2 inhibitor treatment enhances photodynamic therapy-mediated tumor response. Cancer Res 2002;62:3956-3961. [PubMed: 12124326]

12. Ferrario A, Fisher A, Rucker N, Gomer CJ. Celecoxib and NS-398 enhance photodynamic therapy by increasing in vitro apoptosis and decreasing in vivo inflammatory and angiogenic factors. Cancer Res 2005;65:9473-9478. [PubMed: 16230411]

13. Bozkulak O, Wong S, Luna M, Ferrario A, Rucker N, Gulsoy M, Gomer CJ. Multiple components of photodynamic therapy can phosphorylate Akt. Photochem. Photobiol 2007;83:1029-1033. [PubMed: 17880496]

14. Ferrario A, Rucker N, Wong S, Luna M, Gomer CJ. Survivin, a member of the inhibitor of apoptosis family, is induced by photodynamic therapy and is a target for improving treatment response. Cancer Res 2007;67:4989-4995. [PubMed: 17510430]

15. Bagatell R, Whitesell L. Altered hsp90 function in cancer: a unique therapeutic opportunity. Mol. Cancer Ther 2004;3:1021-1030. [PubMed: 15299085]

16. Chaudhury S, Welch TR, Blagg BSJ. Hsp90 as a target for drug development. Chem. Med. Chem 2006;1:1331-1340. [PubMed: 17066389]

17. Tsutsumi S, Neckers L. Extracellular heat shock protein 90: a role for a molecular chaperone in cell motility and cancer metastasis. Cancer Sci 2007;98:1536-1539. [PubMed: 17645779]

18. Kregel KC. Heat shock proteins: modifying factors in physiological stress responses and acquired thermotolerance. J. Appl. Physiol 2002;92:2177-2186. [PubMed: 11960972]

19. Neckers L, Ivy SP. Heat-shock protein 90. Curr. Opin. Oncol 2003;15:419-422. [PubMed: 14624223]

20. Banerji U. Heat shock protein 90 as a drug target: some like it hot. Clin. Cancer Res 2009;15:9-14. [PubMed: 19118027]

21. Powers MV, Workman P. Targeting of multiple signaling pathways by heat shock protein 90 molecular chaperone inhibitors. Endocine-related Cancers 2006;13:s125-s135.

22. Zhang HY, Chung D, Y-Yang C, Neely L, Tsurumoto S, Fan J, Zhang L, Biamonte M, Brekken J, Lundgren K, Burrows FJ. Identification of new biomarkers for clinical trials of Hsp90 inhibitors. Mol. Cancer Ther 2006;5:1256-1264. [PubMed: 16731758]

23. Hopper C. Photodynamic therapy: a clinical reality in the treatment of cancer. Lancet Oncol 2000;1:212-219. [PubMed: 11905638]

24. Dougherty TJ. An update on photodynamic therapy applications. J. Clin. Laser Med. Surg 2002;20:37. [PubMed: 11902352]

25. Tong Z, Singh G, Valerie GK, Rainbow AJ. Activation of the stress-activated JNK and p38 MAP kinases in human cells by Photofrin-mediated photodynamic therapy. J. Photochem. Photobiol. B 2003;15:77-85. [PubMed: 14705642]

26. Verma S, Watt GM, Mai Z, Hasan T. Strategies for enhancing photodynamic therapy effects. Photochem. Photobiol 2007;83:996-1005. [PubMed: 17880492]

27. Sonveaux P, Bronet A, Havanx X, Gregorire V, Dosy C, Balligand JL, Feron O. Irradiation-induced angiogenesis through the up-regulation of the nitric oxide pathway. Cancer Res 2003;63:1012-1019. [PubMed: 12615716]

28. Fohy BN, Schlieman MG, Virudachalam S, Bold RJ. Inhibition of AKT abrogates chemotherapy induced NFkB survival mechanisms: implications for therapy in pancreatic cancer. J. Am. Coll. Surg 2004;198:591-599. [PubMed: 15051014]

29. Workman P, Burrows F, Neckers L, Rosen N. Drugging the cancer chaperone Hsp90: combinatorial therapeutic exploitation of oncogene addiction and tumor stress. Ann. N. Y. Acad. Sci 2007;1113:202-216. [PubMed: 17513464]

30. Ramanathan RK, Egorin MJ, Eiseman J, Ramalingam S, Friedland D, Agarwala SS, Ivy SP, Potter D, Chatta G, Zuhowski EG, Stoller RG, Naret C, Guo J, Belani CP. Phase 1 and pharmacodynamics study of 17-(allylamino)-17-demethoxygeldanamycin in adult patients with refractory advanced cancers. Clin. Cancer Res 2007;13:1769-1774. [PubMed: 17363531] 
31. Heath EI, Hillman DW, Vaishampayan U, Sheng S, Sarkar F, Harper F, Gaskins M, Pitot HC, Tan W, Ivy SP, Pili R, Carducci MA, Erlichman C, Lui G. A Phase II trial of 17-allylamino-17demthoxygeldanamycin in patients with hormone refractory metstatic prostate cancer. Clin. Cancer Res 2008;14:7940-7946. [PubMed: 19047126]

32. Nonaka M, Ikeda H, Inokuchi T. Inhibitory effect of heat shock protein 70 on apoptosis induced by photodynamic therapy in vitro. Photochem. Photobiol 2004;79:94-98. [PubMed: 14982037]

33. Rucker N, Ferrario A, Gomer CJ. C.J. Constitutive over-expression of HSP-70 in thermal resistant tumor cells does not alter sensitivity to porphyrin, chlorin or purpurin mediated PDT. J. Porphyrins Phthalocyanines 2001;5:143-146.

34. Gomer CJ, Ferrario A, Rucker N, Wong S, Lee A. Glucose regulated protein (GRP-78) induction and cellular resistance to oxidative stress mediated by porphyrin photosensitization. Cancer Res 1991;51:6574-6579. [PubMed: 1835901]

35. Gyurkocza B, Plescia J, Raskett CM, Garlick DS, Lowry PA, Carter BZ, Andreeff M, Meli M, Colombo G, Altieri DC. Antileukemic activity of shepherdin and molecular diversity of Hsp-90 inhibitors. J. Natl. Cancer Inst 2006;98:1068-1077. [PubMed: 16882944]

36. banerji U, Sain N, Sharp SY, Valenti M, Asad Y, Ruddle R, Raynaud F, Walton M, Eccles SA, Judson I, Jackman AL, Workman P. An in vitro and in vivo study of the combination of the heat shock protein inhibitor 17-allylamino-17-demethoxygeldanamycin and carboplatin in human ovarian cancer models. Cancer Chemother. Pharmacol 2008;62:769-778. [PubMed: 18193424] 
BA Cells

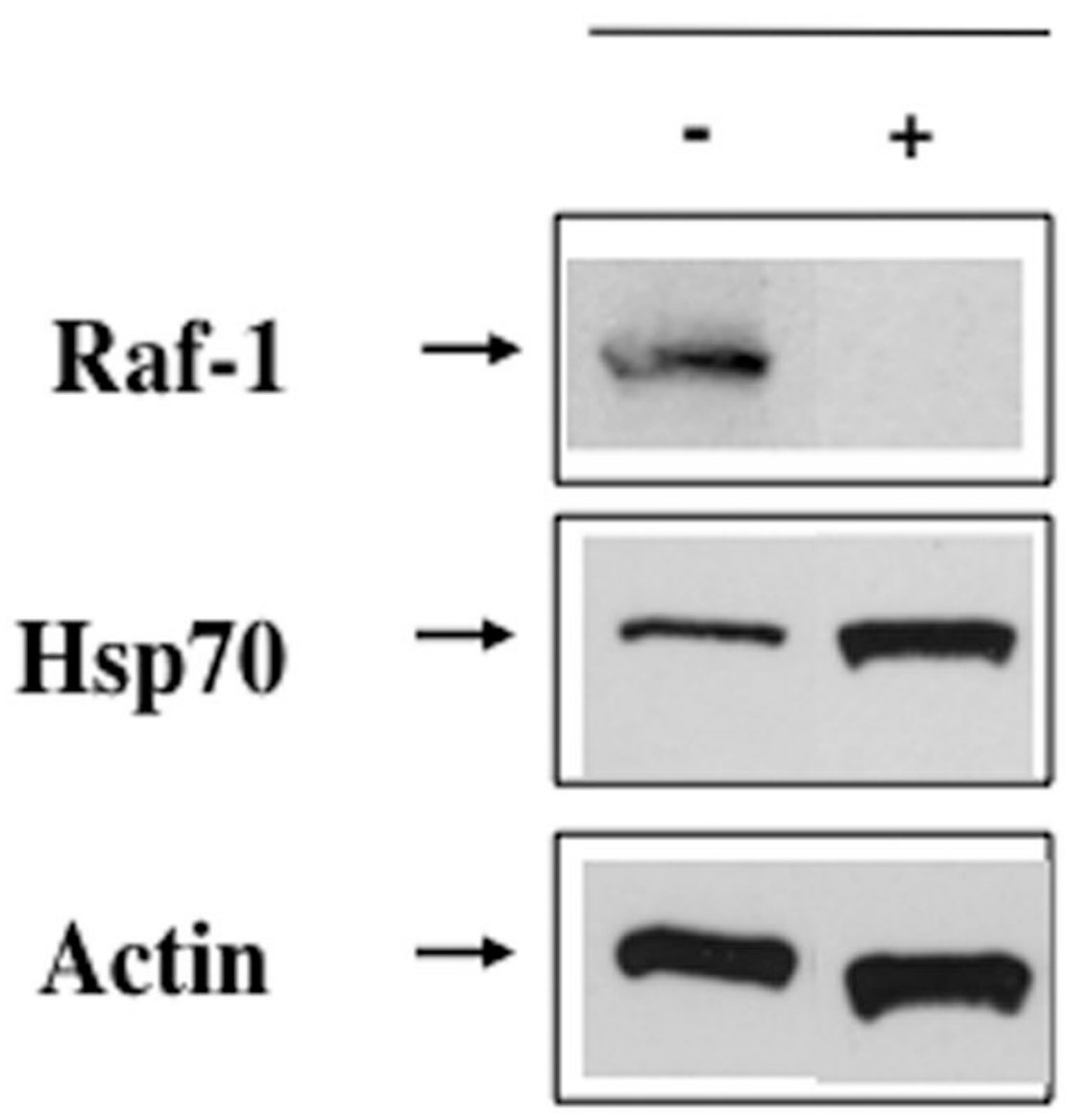




\section{BA Tumor}

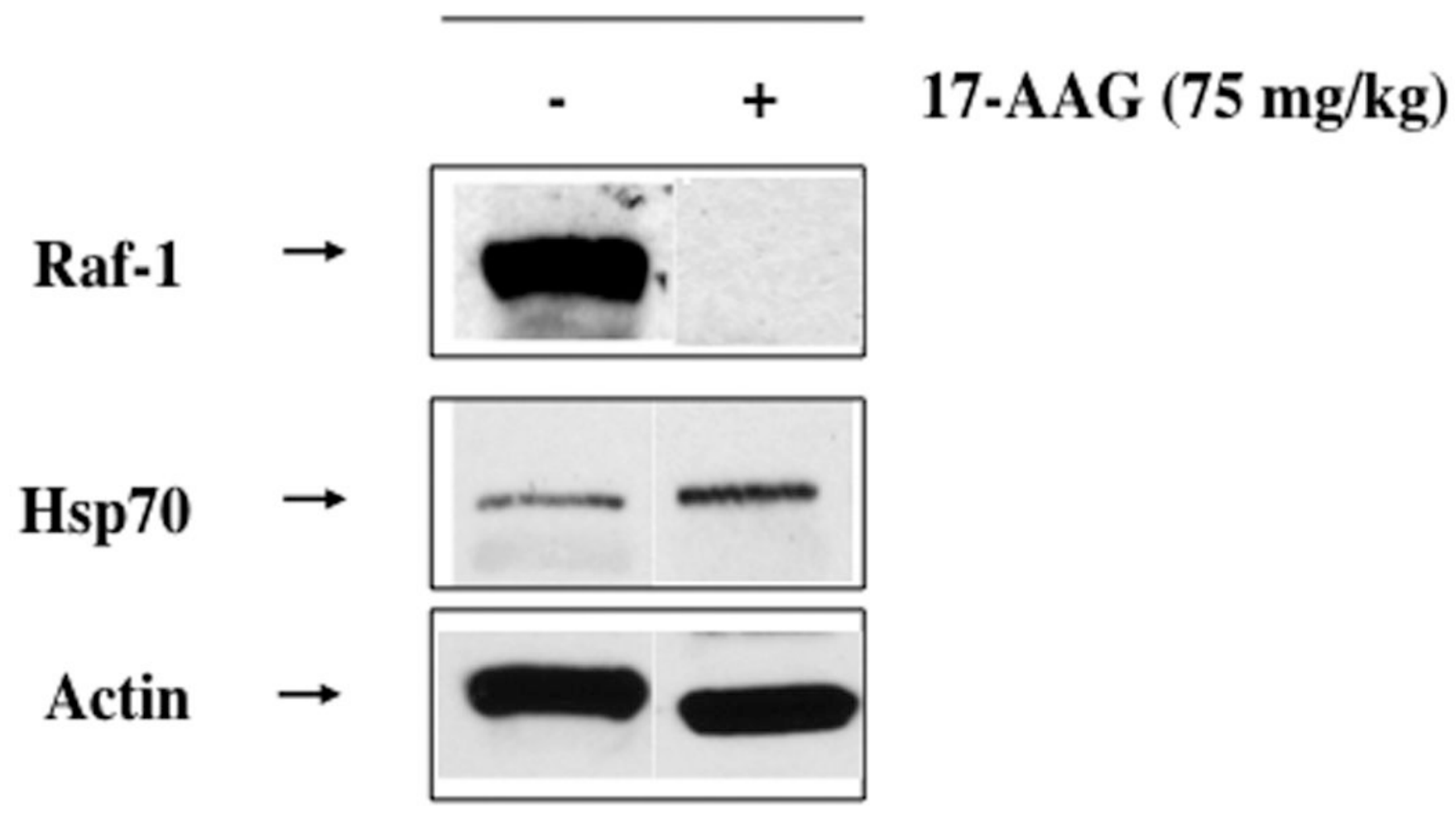

Figure 1.

Biomarker confirmation of Hsp-90 inhibition; 17-AAG inhibits the expression of Raf-1 and induces the expression of Hsp-70 in BA cells and tumors. Cells were incubated for $24 \mathrm{hr}$ in the presence or absence of 17-AAG $(1 \mu \mathrm{M})$. C3H mice with subcutaneous mammary tumors received an ip injection of $17-\mathrm{AAG}(75 \mathrm{mg} / \mathrm{kg})$ and tumor tissues were collected 24 hours later. Cell (A) and tumor (B) lysates were analyzed for Raf- 1 and Hsp-70 protein expression by Western immunoblot using specific antibodies against each protein. Expression of actin, a nonHsp-90 client protein, was used as a loading control. 


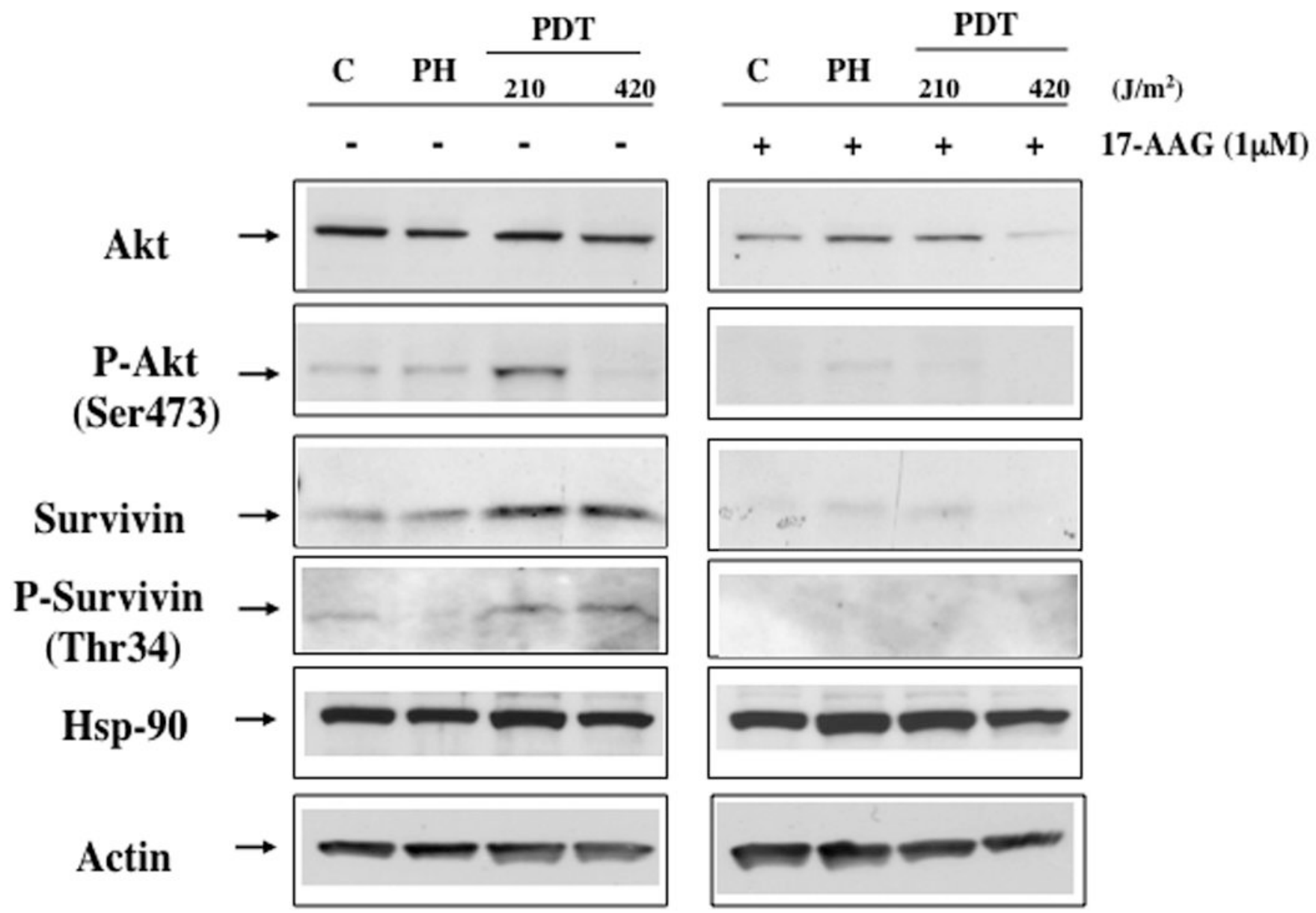



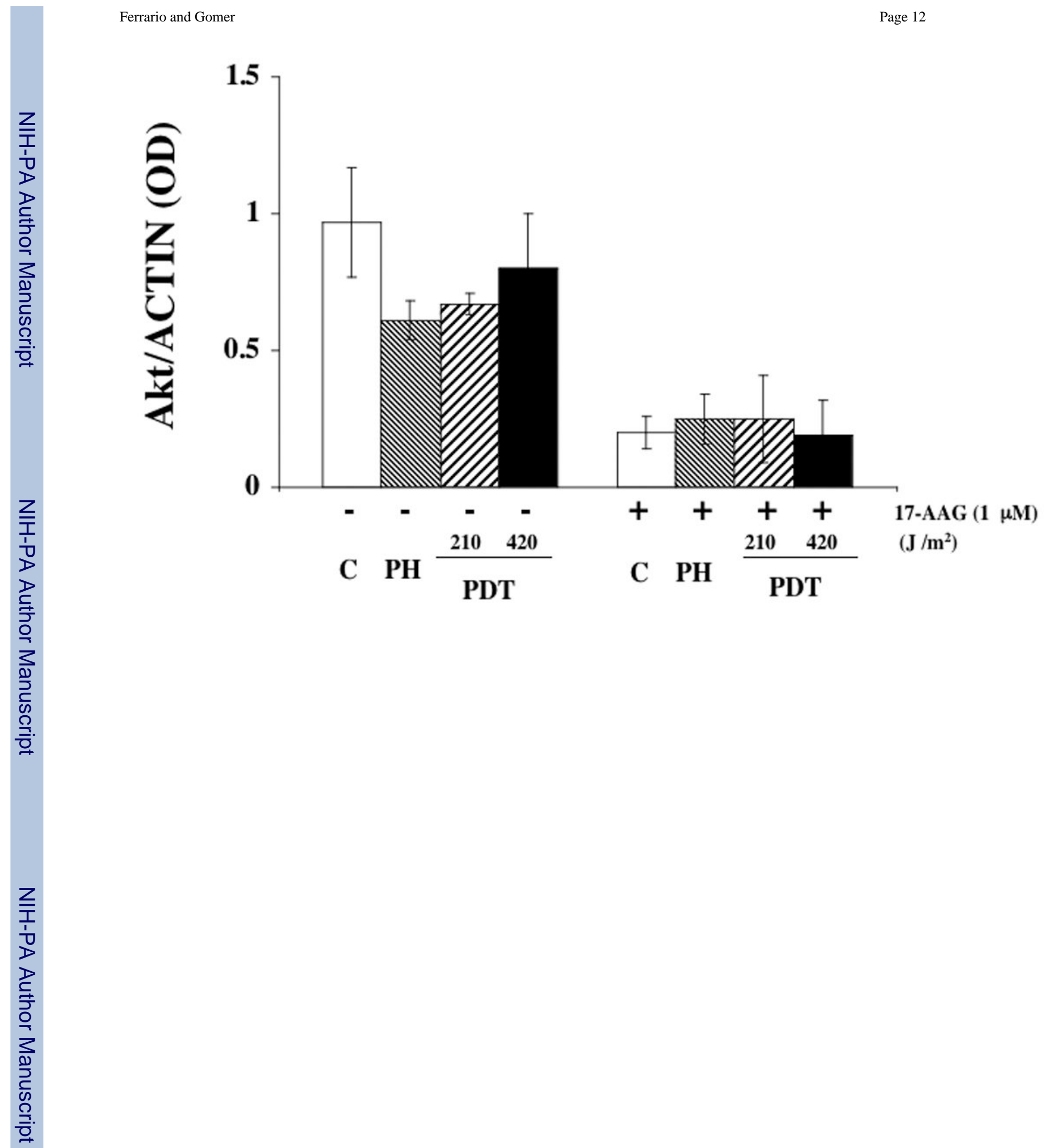


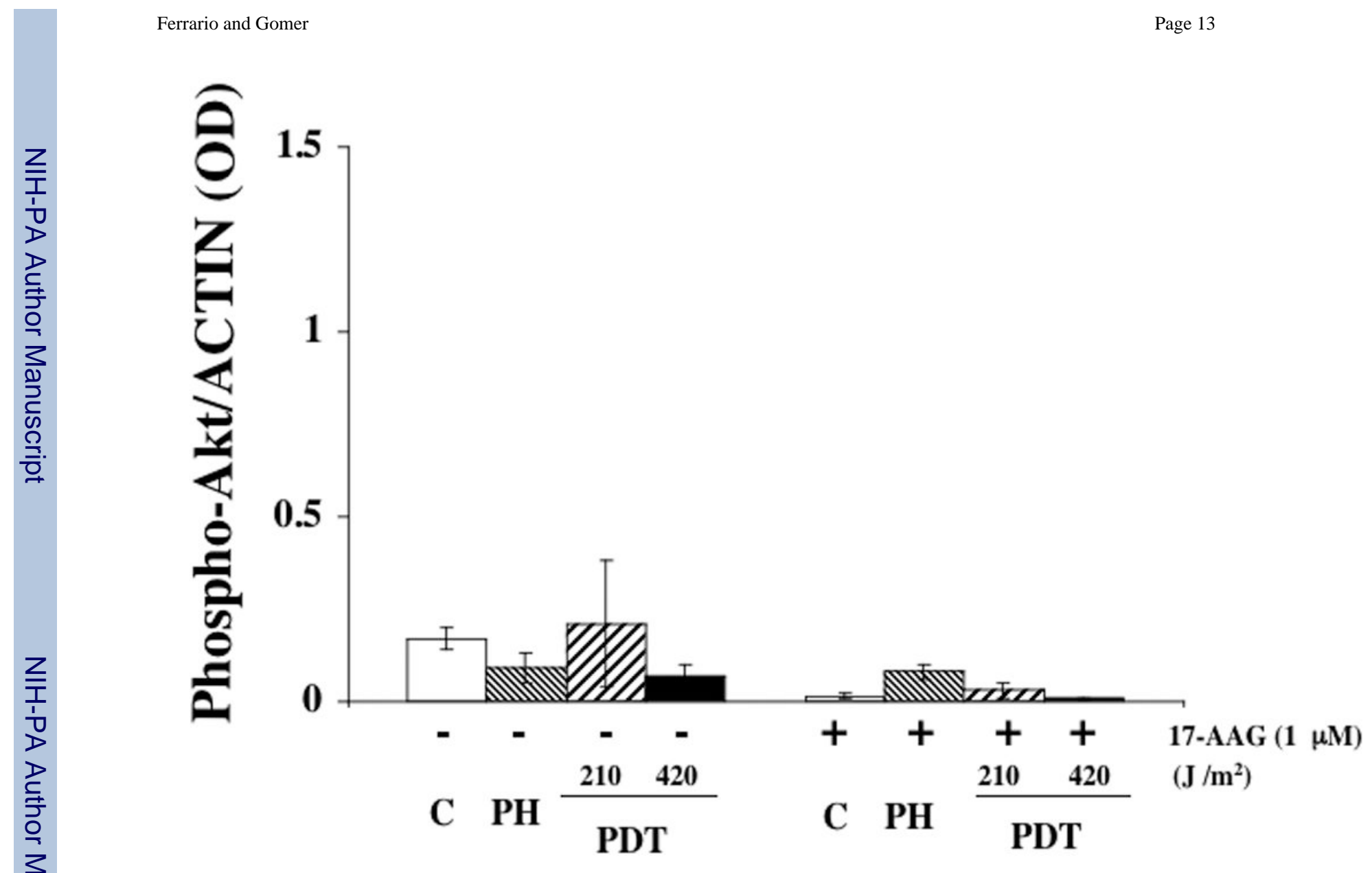




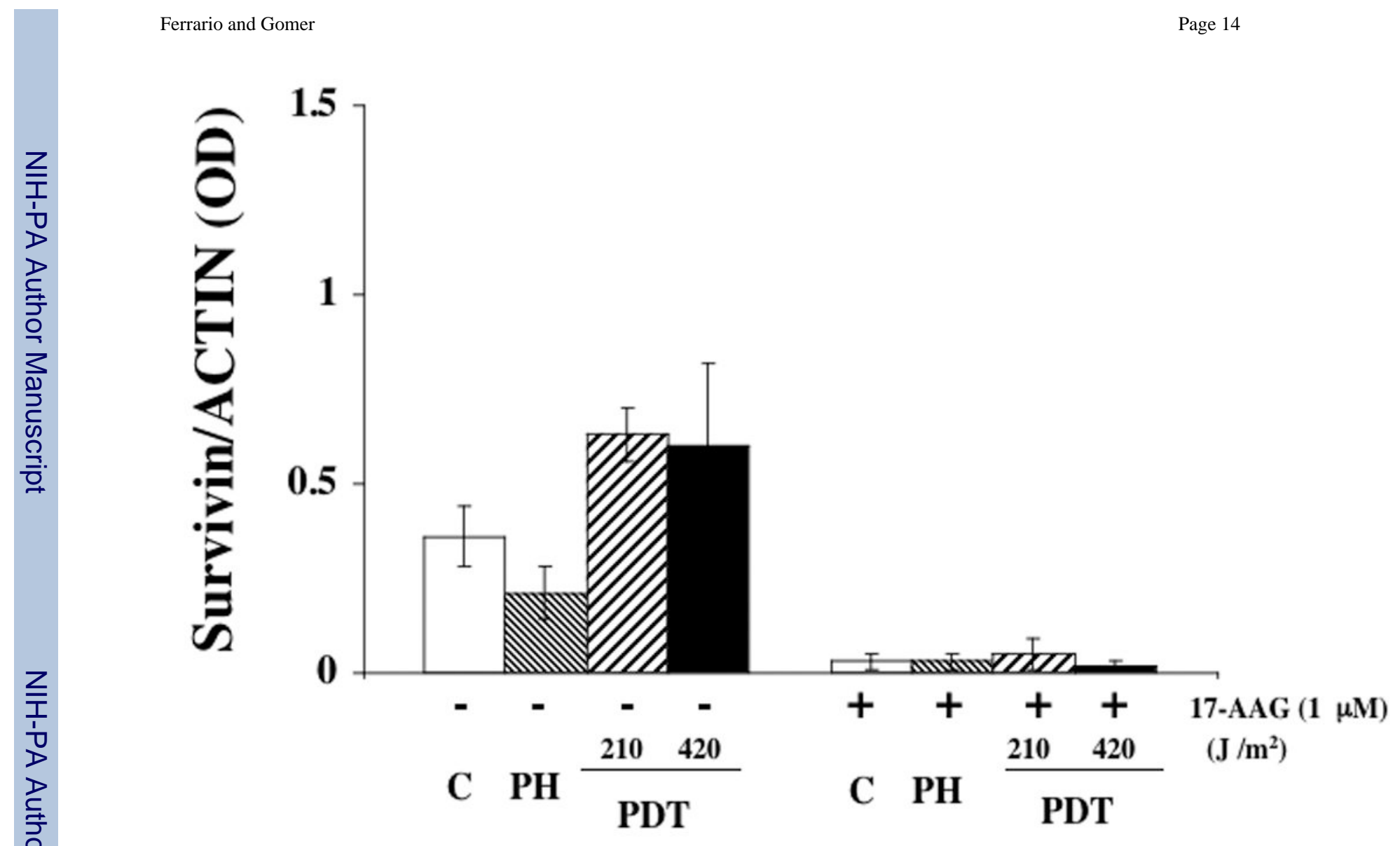




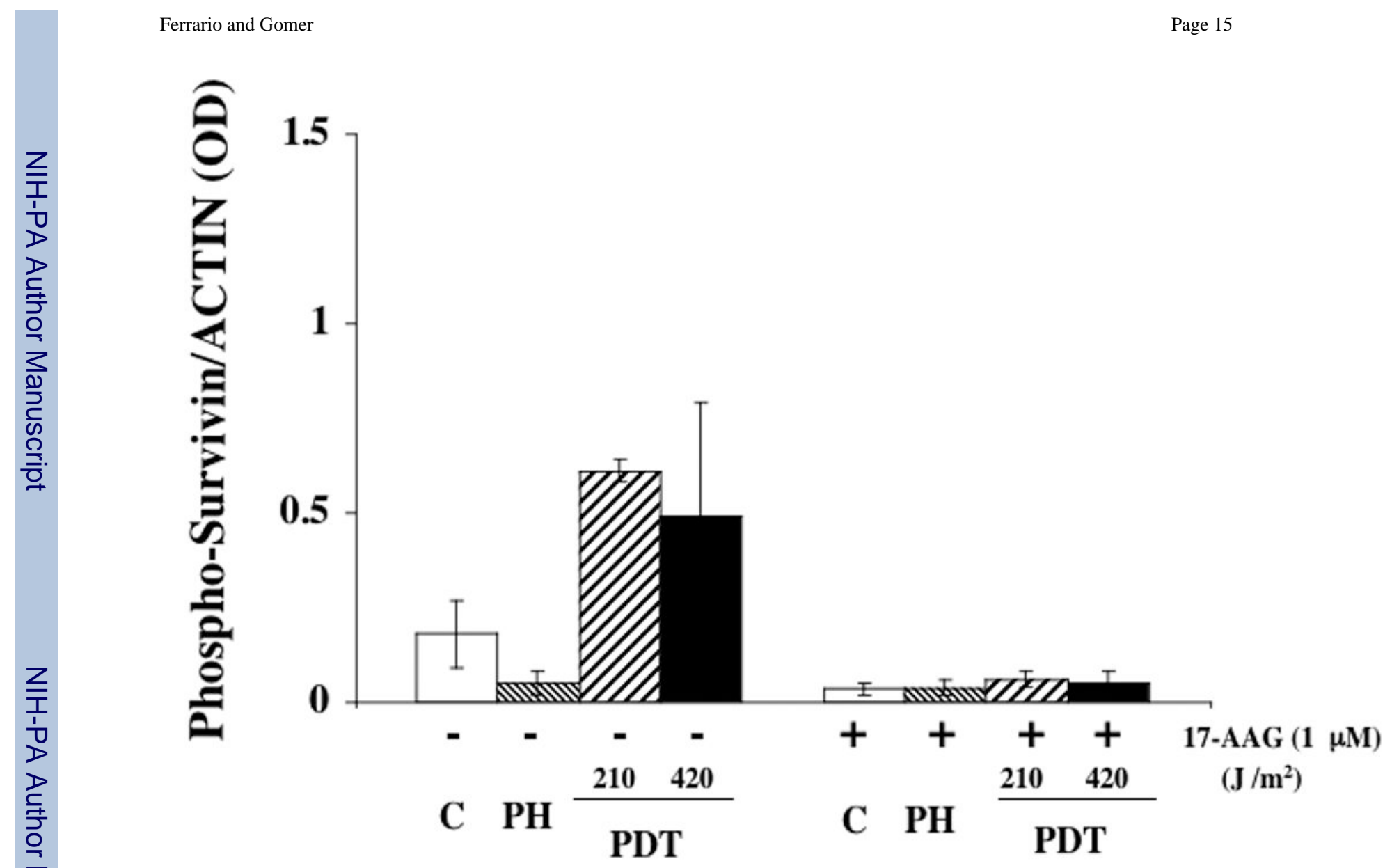




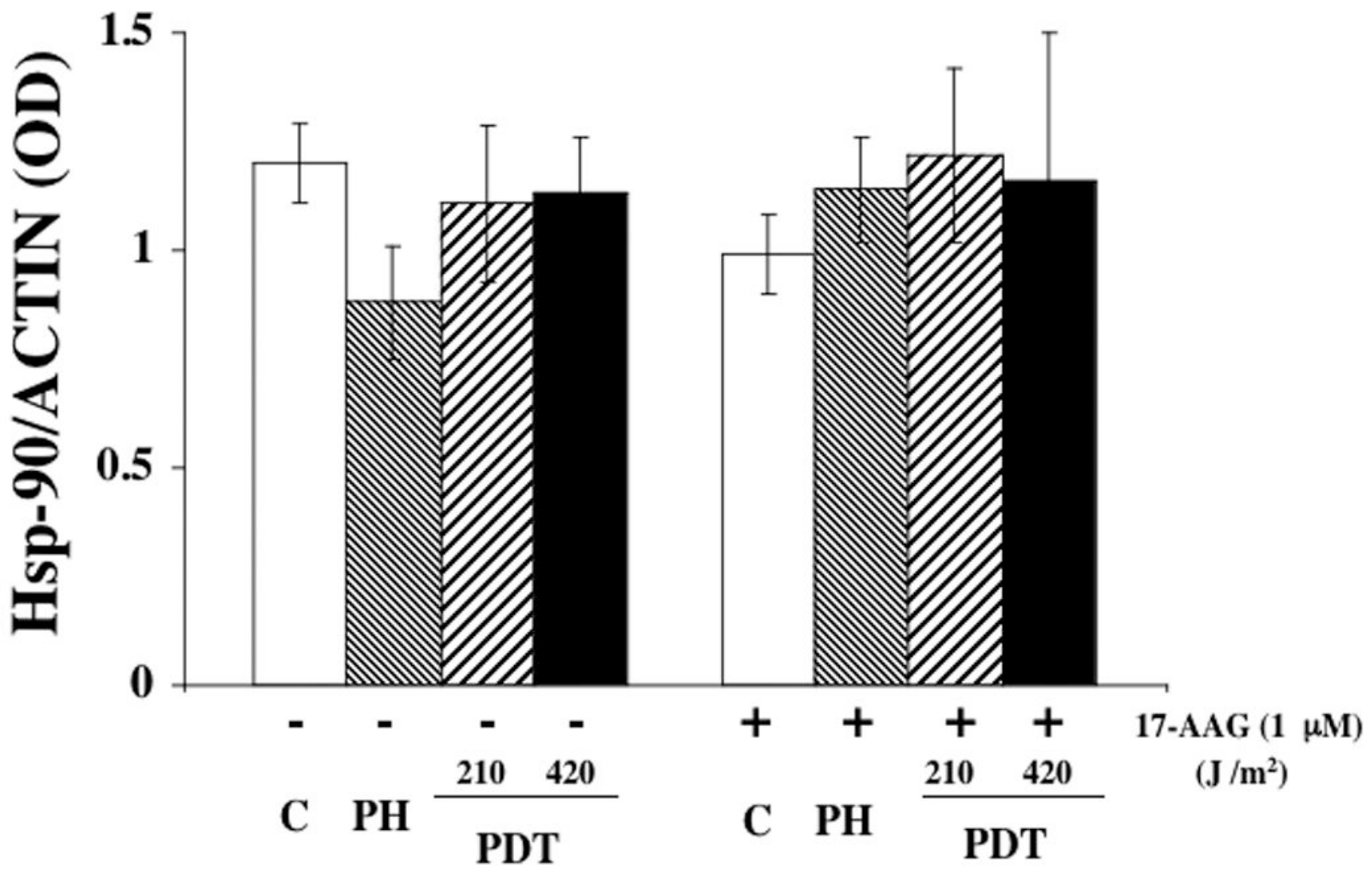

Figure 2.

17-AAG decreases the expression of Hsp-90 client proteins associated with cell growth and proliferation in PDT-treated BA cells. (A) Western immunoblot analysis documenting expression of survivin, phospho-survivin (Thr34), Akt, phospho-Akt (Ser473), Hsp-90, and actin in controls and PDT-treated cells. Cells were incubated with PH $(25 \mu \mathrm{g} / \mathrm{ml})$ in the dark for $16 \mathrm{hr}$ and exposed to red light $\left(210\right.$ or $420 \mathrm{~J} / \mathrm{m}^{2}$ ). Cells were then incubated in the dark for an additional $24 \mathrm{hr}$ in the presence or absence of 17-AAG $(1 \mu \mathrm{M})$. Lysates from control and treated cells were collected and analyzed for protein expression using commercially available antibodies. Actin expression was used to monitor protein loading. Densitometric measurements (averages $\pm \mathrm{SE}$ ) from immunoblots of three separate experiments are shown for Akt (B), phospho-Akt (Ser473) (C), survivin (D), phospho-survivin (Thr34) (E) and Hsp-90 (F). 

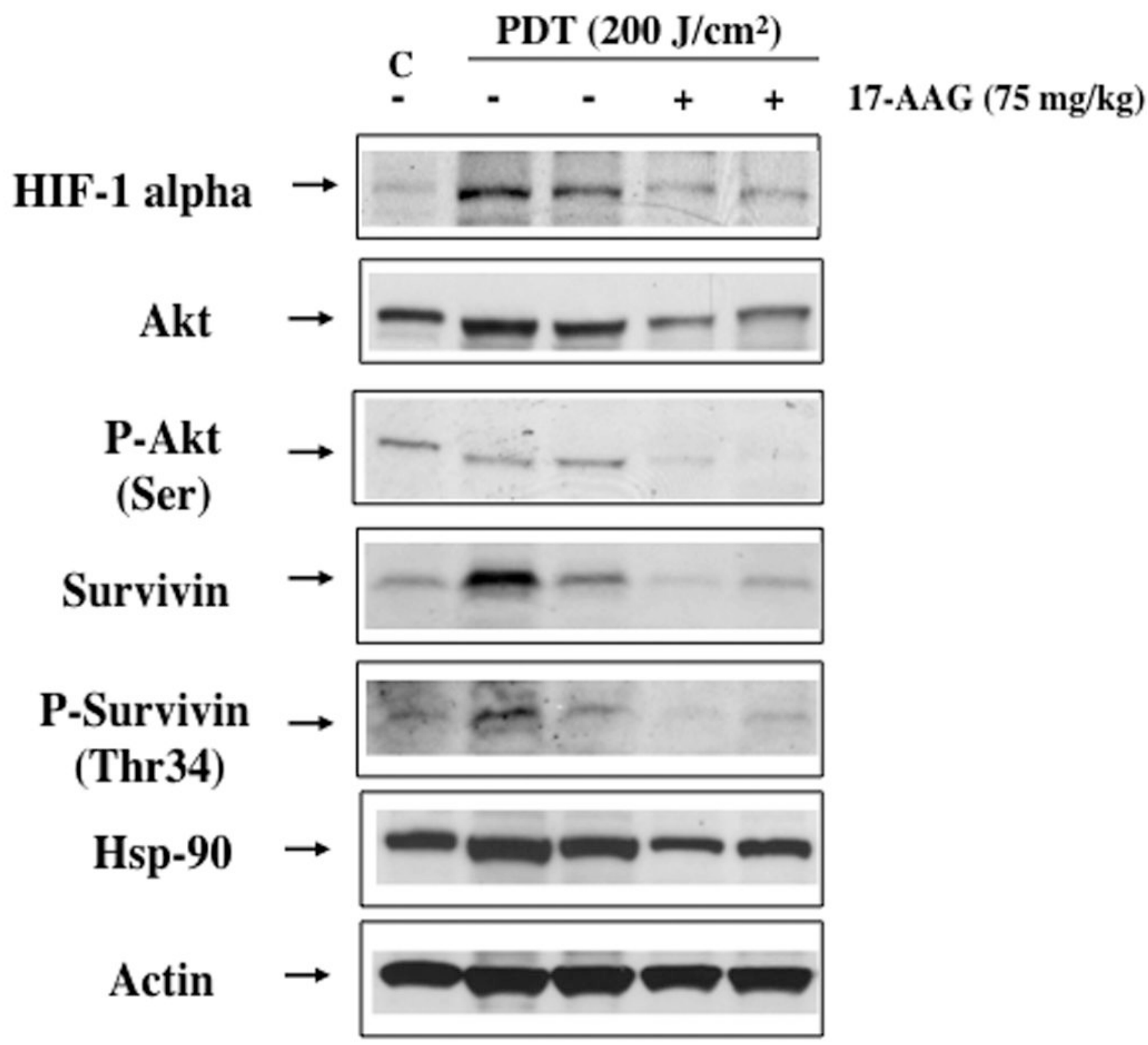


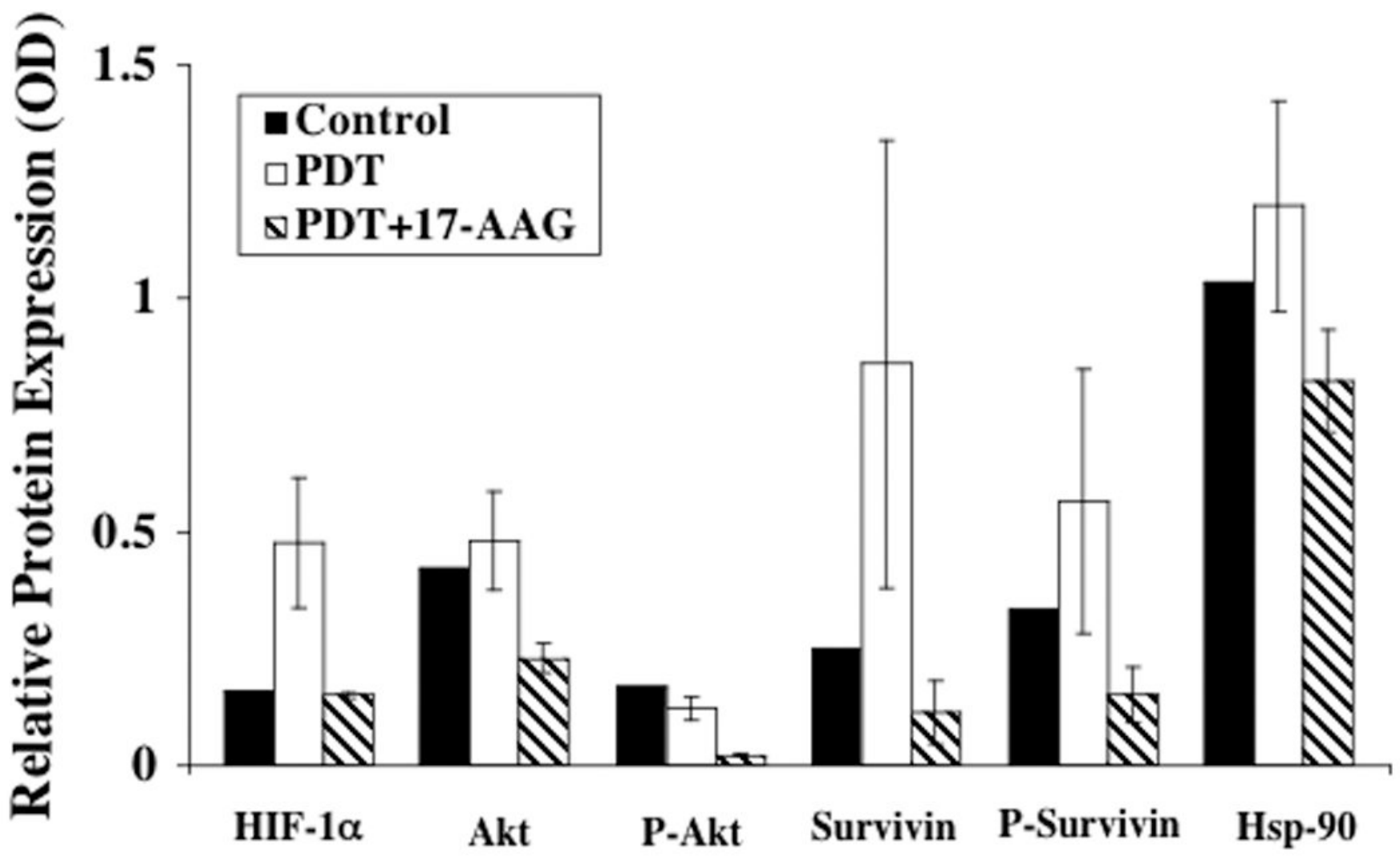

Figure 3.

17-AAG decreases the expression of Hsp-90 client proteins associated with cell growth and angiogenesis in PDT-treated BA tumors. $\mathrm{C} 3 \mathrm{H} / \mathrm{HeJ}$ mice with subcutaneously transplanted BA tumors measuring 6-7 mm in diameter were injected iv with $\mathrm{PH}(5 \mathrm{mg} / \mathrm{kg})$ and then $24 \mathrm{hr}$ later tumors were exposed to a $200 \mathrm{~J} / \mathrm{cm}^{2}$ dose of $630 \mathrm{~nm}$ light. A group of mice received an ip injection of $17-\mathrm{AAG}$ at a dose of $75 \mathrm{mg} / \mathrm{kg}$ either alone or immediately after PDT. Tumor lysates were collected $2 \mathrm{hr}$ after treatment. (A) Western immunoblot analysis show expression profiles for HIF-1 $\alpha$, Akt, phospho-Akt (Ser473), survivin, phospho-survivin (Thr34), Hsp-90 and actin using commercially available antibodies. (B) densitometric readings (average \pm SE) obtained from the immunoblots of 3 samples. 

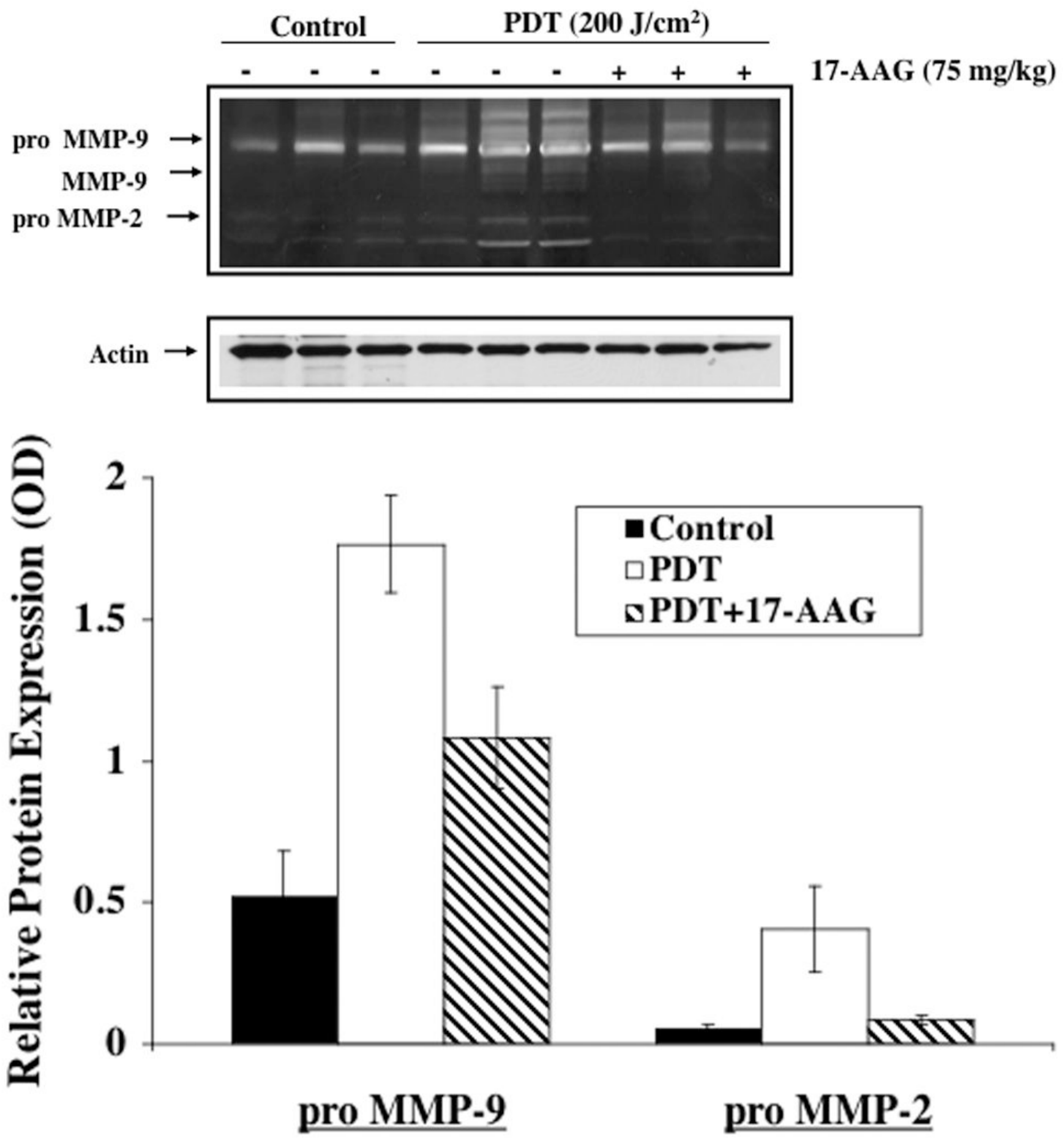


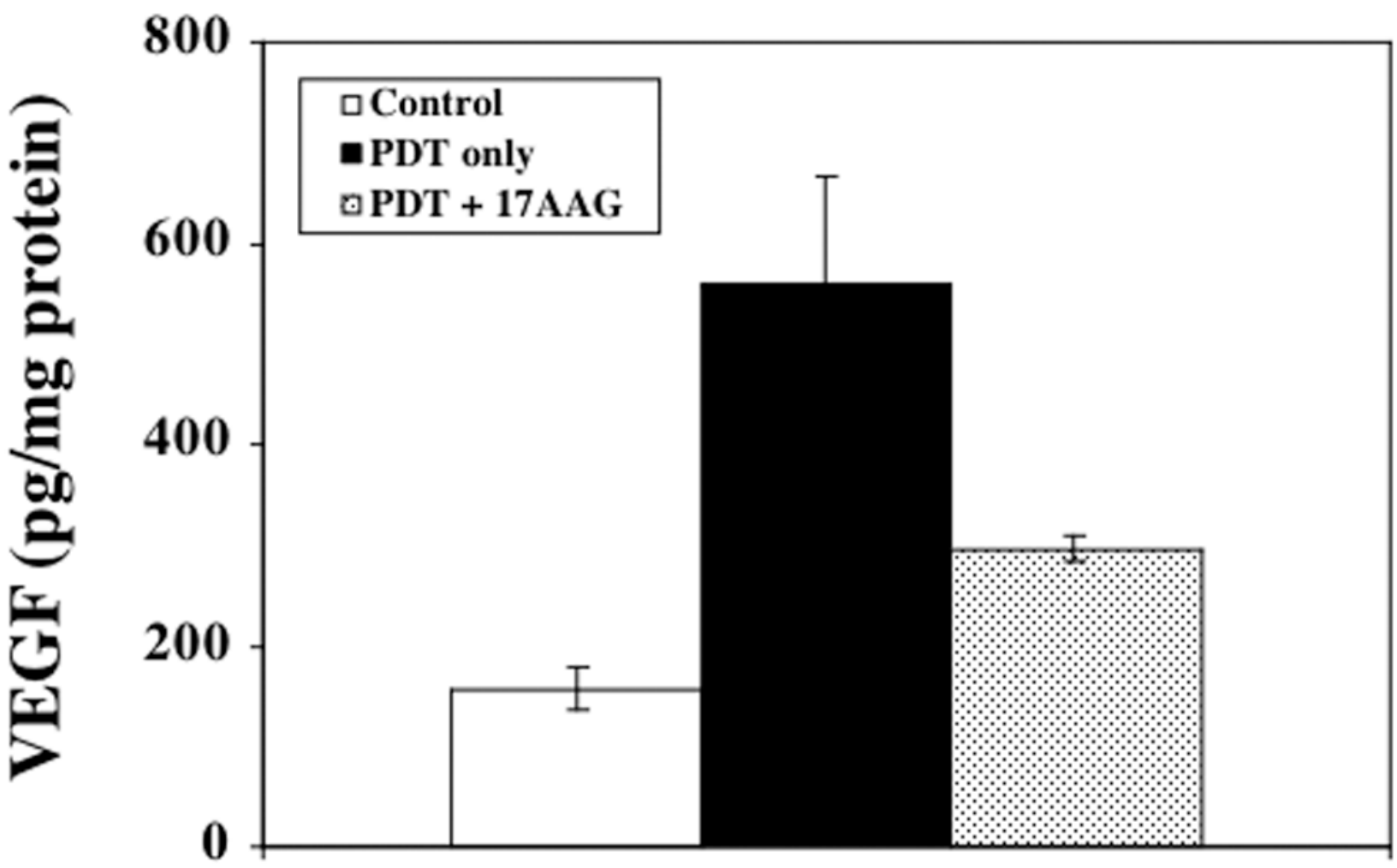

Figure 4.

17-AAG attenuates the expression of proteins associated with invasion and angiogenesis in PDT-treated BA tumors. C3H/HeJ mice with subcutaneously transplanted BA tumors measuring 6-7 mm in diameter were injected iv with $\mathrm{PH}(5 \mathrm{mg} / \mathrm{kg})$ and then $24 \mathrm{hr}$ later tumors were exposed to a $200 \mathrm{~J} / \mathrm{cm}^{2}$ dose of $630 \mathrm{~nm}$ light. A group of mice received an ip injection of $17-\mathrm{AAG}$ at the dose of $75 \mathrm{mg} / \mathrm{kg}$ either alone or immediately after PDT. Tumor lysates were collected $2 \mathrm{hr}$ after treatment for analysis. (A) SDS-polyacrylamide gelatin zymography documenting the presence of MMP-9 and MMP-2 in treated samples and control. (B) Corresponding densitometric readings of the proteolytic bands associated to MMP-9 and MMP-2 enzymatic activity. (C) Levels of VEGF determined by the Quantikine M mouse ELISA kit. Means $\pm \mathrm{SE}$ are plotted. $\mathrm{N}=3$ per group. 


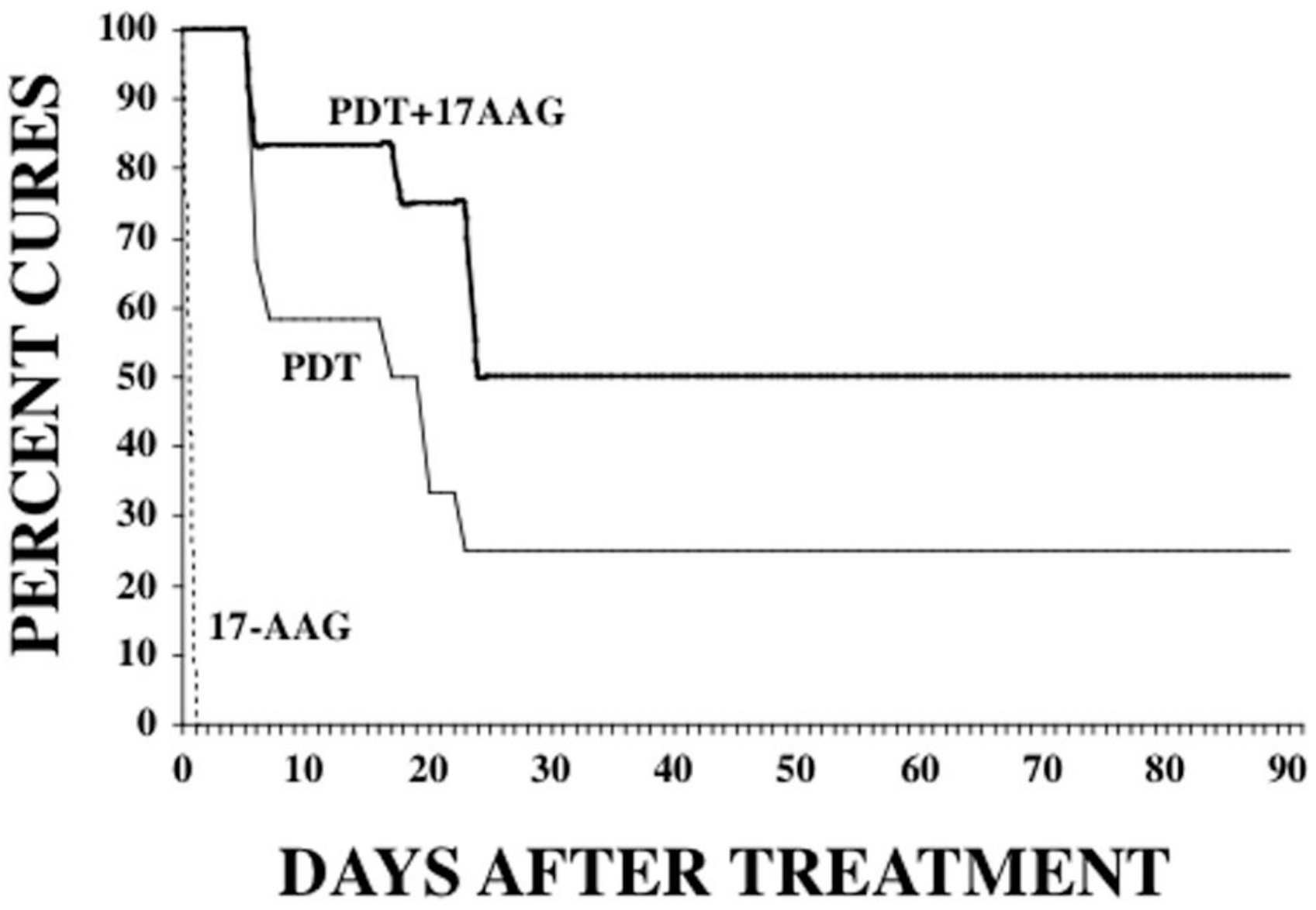

Figure 5.

17-AAG enhances the tumoricidal action of PDT. Mice with transplanted BA tumors were entered into treatment groups when lesions reached 6-7 mm in diameter. Test groups included controls, PDT alone, 17-AAG alone, and PDT plus 17-AAG. For PDT, mice received PH (5 $\mathrm{mg} / \mathrm{kg}$ ) by iv injection and $24 \mathrm{hr}$ later tumors were exposed to a $200 \mathrm{~J} / \mathrm{cm}^{2}$ dose of $630 \mathrm{~nm}$ light delivered at $75 \mathrm{~mW} / \mathrm{cm}^{2}$. 17-AAG $(75 \mathrm{mg} / \mathrm{kg})$ was administered by ip injection thrice weekly $(\mathrm{M}, \mathrm{W}, \mathrm{F})$ for two weeks and the 17-AAG administration was started immediately after the completion of the PDT treatment. Mice were monitored for recurrences three times a week for a 90-days period. Percent cures are plotted as a function of time after treatment. $\mathrm{N}=12$ per group. A statistically significant difference $(\mathrm{p}<0.05)$ was observed for PDT plus 17-AAG versus PDT alone. 